\title{
Integrated Nutrient Management of Pea-Capsicum-Radish Cropping Sequence in Sub-Temperate Climate of North-Western Himalayas
}

\author{
Monika Sharma*, A.K. Sharma and Shilpa \\ Department of Vegetable Science, College of Horticulture, Dr YS Parmar University of \\ Horticulture and Forestry Nauni, Solan-173 230, India \\ *Corresponding author
}

\section{A B S T R A C T}

\section{Keywords \\ IPNS, Organic manures, PGPR, Growth, Yield \\ Article Info \\ Accepted: \\ 07 February 2018 Available Online: 10 March 2018}

\begin{abstract}
A field experiment was carried out for two consecutive years (2014-2016) at Dr YS Parmar University of Horticulture and Forestry, Nauni Solan, (HP) to evolve INPS system for higher growth and yield. The experiment was laid out in RBD with 03 replicates comprising 13 integrated combinations of inorganic and organics including Biofertilizers/PGPR. The reduced RDF was supplemented through organic manures (EC, $\mathrm{SMC}$ ) on $\mathrm{N}$ eq. basis. Integrated use of manures, fertilizers and bio-fertilisers/ PGPR significantly influenced yield and plant growth attributes in all three crops. The highest yields were recorded in treatment comprising of $90 \% \mathrm{RDF}+10 \% \mathrm{SMC}+\mathrm{FYM}+\mathrm{Bio}-$ fertilizer/PGPR $\left(\mathrm{T}_{6}\right)$ with an average increase of $14.11 \%, 24.27 \%$ and $15.31 \%$ over recommended practise in pea, capsicum and radish respectively.
\end{abstract}

\section{Introduction}

In the last few decades India has made a quantum jump in vegetable production, securing the second position after China in the world with an area of 9541 thousand hectares and production of 168.3 million tonnes (Anonymous, 2015). Our demand of vegetables will be 225 million tonnes by 2020 and 350 million tonnes by 2030, to meet out the requirement of $300 \mathrm{~g}$ per capita per day for balanced diet (Anonymous, 2011).

In the era of crop diversification, vegetable cultivation in Himachal Pradesh in general and in mid-hills in particular is gaining significant importance on account of favourable agro- climatic conditions for growing quality offseason vegetables, e.g. pea, tomato, capsicum cauliflower, cabbage, French bean, etc. Pea capsicum - radish is one of the remunerative cropping sequences prevalent in mid hill areas of the state.

For enhancing high yield of vegetable crops, soil health is crucial factor. Unfortunately, deteriorating soil fertility is principally responsible for low yield of vegetables across the country. Enhancing soil fertility and crop productivity through use of chemical fertilizers has often negatively affected the complex system of biogeochemical cycles (Roberts 2008). For example, fertilizer use has caused leaching and run-off of nutrients, 
especially nitrogen $(\mathrm{N})$ and phosphorus $(\mathrm{P})$, leading to environmental degradation. Therefore, there must be a balance between optimal nutrient use efficiency and optimal crop productivity. Amongst the several indicators of soil degradation, over mining of nutrients is considered to be the major concern particularly under vegetable based cropping systems, which have high irrigation requirement. This is happening so because nutrient removal by crops from soil has far exceeded their replenishment through fertilizers and manures causing negative balance of nutrients in soil (Gangawar and Prasad, 2005). Therefore, interest has grown in environmentally sustainable agricultural practices.

The potential way to decrease negative environmental impacts resulting from inefficient use of chemical fertilizers is to follow integrated use of organic manures, mineral fertilizers and inoculation with biofertilisers / plant growth promoting rhizobacteria (PGPR). This will in turn help to meet out the nutrient requirement of the crops as well as maintaining sustainability in terms of productivity and soil fertility.

Hence, the present study, had therefore, been aimed to evolve integrated plant nutrient supply system for pea- capsicum- radish based cropping systems in mid hills of Himachal Pradesh.

\section{Materials and Methods}

Experiment was carried out for two years (2014-2016) at Dr YS Parmar University of Horticulture and Forestry, Nauni Solan, (HP) to evolve INPS system for higher productivity and soil health. Agro-climatically, the location falls in the mid hill zone of $\mathrm{HP}$ and is characterized by sub-temperate to sub-tropical climate with moderate rainfall (1000-1300 $\mathrm{mm})$. The experiment was laid out in RBD with 03 replicates comprising 13 integrated combinations of inorganic and organics including Bio-fertilizers/PGPR viz. $\mathrm{T}_{1}: \mathrm{RPF}=$ $(\mathrm{RDF}(\mathrm{NPK})+\mathrm{FYM}), \mathrm{T}_{2}: 90 \% \mathrm{RDF}+10 \%$ $\mathrm{EC}+\mathrm{FYM}+$ Bio-fertilizer/PGPR $\mathrm{T}_{3}: 80 \%$ $\mathrm{RDF}+10 \% \mathrm{EC}+\mathrm{FYM}+$ Biofertilizer/PGPR, $\mathrm{T}_{4}: 70 \% \mathrm{RDF}+10 \% \mathrm{EC}+$ FYM + Bio-fertilizer/PGPR, T $: 60 \%$ RDF + $10 \% \mathrm{EC}+\mathrm{FYM}+$ Bio-fertilizer/PGPR, $\mathrm{T}_{6}$ : $90 \% \mathrm{RDF}+10 \% \mathrm{SMC}+\mathrm{FYM}+$ Biofertilizer/PGPR, $\mathrm{T}_{7}: 80 \% \mathrm{RDF}+10 \% \mathrm{SMC}$ + FYM + Bio-fertilizer/PGPR, $\mathrm{T}_{8}: 70 \% \mathrm{RDF}$ $+10 \%$ SMC + FYM + Bio-fertilizer/PGPR, $\mathrm{T}_{9}: 60 \% \mathrm{RDF}+10 \% \mathrm{SMC}+\mathrm{FYM}+\mathrm{Bio}-$ fertilizer/PGPR, $\mathrm{T}_{10}: 90 \% \mathrm{RDF}+\mathrm{FYM}+$ Bio-fertilizer/PGPR, $\mathrm{T}_{11}: 80 \% \mathrm{RDF}+\mathrm{FYM}+$ Bio-fertilizer/PGPR, $\mathrm{T}_{12}: 70 \% \mathrm{RDF}+\mathrm{FYM}+$ Bio-fertilizer/PGPR and $\mathrm{T}_{13}: 60 \% \mathrm{RDF}+$ FYM + Bio-fertilizer/PGPR.

In pea and radish, seeds as per treatment were inoculated with Rhizobium and Azotobacter, respectively@200 g/10 kg of seeds and mixed thoroughly, while PSB in both the crops was applied as soil application @ 5 $\mathrm{kg} / \mathrm{ha}$ by thoroughly mixing with manures and spread as cover over seeds sown in field. Seed/seedlings of sweet pepper were soaked in liquid culture of bacterium (Bacillus subtilis) of population density (1.5 OD at $540 \mathrm{~nm})$ that resulted in the formation of $10^{8} \mathrm{cfu} / \mathrm{ml}$ of bacterial isolate or sterilized water (as per treatment), in glassware for 3-4 hours and sown/transplanted thereafter. The crops i.e. pea, capsicum and radish were sown/transplanted at a standard spacings of 60 x 7.5, 60 x 45 and $30 \times 7.5 \mathrm{~cm}$, respectively

Spent mushroom compost (SMC), a residual compost waste generated by the mushroom production industry, consists of a combination of wheat straw, chicken manure, wheat bran/cotton seed meal, urea and gypsum, composted together and have 0.98 percent nitrogen content. Since, Solan is a known mushroom city, it is readily available here. 
The enriched compost (EC) was prepared by decomposing different vegetative farm wastes available. A layer of farm refuse $(30 \mathrm{~cm}$ thickness) was spread over thin layer of slurry of cow dung at the surface of the trench. The slurry of cow dung was again sprinkled onto the layer of refuse. Afterwards, enrichment with nitrogen and phosphorus was done in the form of urea @ $200 \mathrm{~g}$ and single super phosphate (SSP) @ 400 g per layer. Four layer of farm wastes were laid out in the pit and heap was raised to a height of about $50 \mathrm{~cm}$ above the ground level and then top was plastered with a thin layer of soil. Compost in making was turned twice (at bi-monthly interval) to facilitate aeration. The compost was ready for use in six months. It has $0.5 \%$ of nitrogen.

The recommended dose of fertilisers for vegetables in an annual sequence were; pea: 25:60:60 NPK + 200 q FYM/ha, capsicum; 100:76:54 NPK + 200 q FYM/ha and radish; 25:48:36 NPK + 100 q FYM/ha. Nitrogen $\left(1 / 2-1 / 3^{\text {rd }}\right)$, phosphorus and potash as per treatments were given to all the treatment plots as basal dressing. The remaining $\mathrm{N}$ was given in splits as prescribed for respective crop in the sequence. Similarly, recommended uniform dose of FYM to all the plots and the other manures viz. SMC and EC as per treatment on $\mathrm{N}$ eq. basis for reduced $\mathrm{RDF}$ (NPK) were incorporated at the time of preparation of individual plot manually. The data on important growth, yield attributes and yield were recorded and analysed as per Panse and Sukhatme (2000) for Randomized Complete Block Design, using MS-Excel and OPSTAT (Sheoron et al., 1998).

\section{Results and Discussion}

\section{Growth parameters}

Application of integrated use of organic manures, chemical fertilisers and bio-
fertlisers/PGPR significantly influenced the plant growth in all the three crops grown in an annual sequence. In pea, perusal of pooled over two year's data in Table 1 exhibited tallest plants $(105.26 \mathrm{~cm})$ in recommended package of practice (RPF) i.e. $\mathrm{T}_{1}$. However, the bio-inoculated modules having $10 \%$ reduced dose of recommended fertilizers (NPK) with or without simultaneous and equivalent (on $\mathrm{N}$ eq. basis) substitution of the same with organics EC or SMC viz. $\mathrm{T}_{6}, \mathrm{~T}_{10}, \mathrm{~T}_{2}$ and $\mathrm{T}_{7}$ recorded 104.41, 103.41, 103.27 and $102.19 \mathrm{~cm}$ tall plants, respectively and were statistically at par to the RPF. As far branching, maximum branches (4.82) in pea were observed through module $\mathrm{T}_{6}(90 \% \mathrm{RDF}$ $+10 \%$ SMC + Bio-fertilizer/ PGPR). In capsicum also, RPF $\left(\mathrm{T}_{1}\right)$ resulted in tallest plants $(64.45 \mathrm{~cm})$ which was found to be statistically on par to $\mathrm{T}_{6}, \mathrm{~T}_{2}$ and $\mathrm{T}_{10}$ which recorded 64.25, 63.63 and $63.38 \mathrm{~cm}$ tall plants, respectively. Significantly highest number of branches (4.55) was also observed by the same treatment $\left(\mathrm{T}_{1}\right)$ which determined tallest plants followed by statistically equal branching in integrated modules $\mathrm{T}_{6}$ and $\mathrm{T}_{7}$ which recorded 4.47 and 4.38 branches/plant, respectively. In radish, the mean leaf length $(21.01 \mathrm{~cm})$ and leaf breadth maximum $(9.88$ $\mathrm{cm})$ was observed to be maximum with $\mathrm{T}_{6}$, which is again a high supportive inorganic (90 $\%$ NPK) with $10 \%$ of RDF (on N eq. basis) supplemented through organic manure i.e. SMC. The growth attributes in all the three crops in a sequence under study recorded linear decrease in respective values w.r.t. growth parameters with the successive reduction in inorganic mineralization below 90 percent with or without equivalent substitution ( $\mathrm{N}$ basis) through any of the inorganics (EC or SMC).

Mukharjee (2016) working with pea crop, recorded maximum plant height $(46.74 \mathrm{~cm})$ with full dose of RDF (30: 60: $40 \mathrm{~kg} / \mathrm{ha}$ NPK) along with Rhizobium and PSB, while module 
comprising $75 \% \mathrm{RDF}+$ vermicompost + Rhizobium + PSB recorded maximum branches (5.60), yet the difference with the former utilizing full dose of RDF was nonsignificant. Bhathal and Kumar (2016) also observed maximum plant height $(99.66 \mathrm{~cm})$ and branching (15.66) in cluster bean through $100 \%$ inorganic NPK followed by at par growth performance $(96.33$ and $15.33 \mathrm{~cm}$ ) by the application of $75 \%$ NPK inorganically and rest $25 \%$ through poultry manure. Sharma et al., (2014), while studying INM in vegetable sequence comprising cauliflowerFrench bean- okra found maximum vegetative growth in respective vegetables with an INM module comprising $20 \mathrm{t}$ vermicompost/ha +75 $\%$ of the recommended NPK + PGPR. The recommended practise i.e. $20 \mathrm{t}$ farmyard manure/ha $+100 \%$ NPK was at par to the former but significantly superior to the sole application of fertilisers NPK @ 50:40:50 $\mathrm{kg} / \mathrm{ha}$.

In pepper, similar results have been reported by Alam et al., (2016) wherein; the tallest plants were recorded in treatment combination that was fertilised with $75 \%$ RDF through mineral fertilisers and remaining $25 \%$ through organic manure i.e. poultry manure slurry $(81.35 \mathrm{~cm})$ or poultry manure $(78.04 \mathrm{~cm})$ visa-vis RDF (100\%) which recorded $75.71 \mathrm{~cm}$ tall plant. Similarly, Ashgar et al., (2006) noticed highest number of leaves (11.79) and leaf area $\left(254.73 \mathrm{~cm}^{2}\right)$ of radish in treatment plot which was fertilised with enriched compost $+100 \%$ recommended dose of nitrogen (RDN) vis- a- vis compost $+75 \%$ RDN (11.79 and 235.82) or absolute RDN @ $60 \mathrm{~kg} / \mathrm{ha}$ (11.70 and 171.01). Similar to the present investigation, all the above studies explained the enhancement of vegetative growth (plant height and number of branches) with higher application of inorganic (NPK) to the direct effect of higher amount of inorganic nitrogen, which is an integral part of protein and chlorophyll molecules which might have increased the foliage of the plants and thereby enhanced the photosynthesis leading to high biomass production. It may also be due to the cell elongation by the presence of nitrogenous compounds. Nitrogen being a constituent of amino acids, nucleotides, nucleic acids, a number of co-enzymes, auxins, cytokinins and alkaloids, induces cell elongation, cell enlargement and cell division. Integration or substitution of organic manures on equivalence basis for reduced synthetic fertilization produced the best or equally best response of growth parameters in the above (including present investigation) which may be attributed to high initial microbial load supported by sufficient quantity of organic carbon to be later used for microbial proliferation and consequently releasing the nutrients that readily assimilates, supporting the biotic principle of carbon sequestration through improved biomass production as explained by Sanyal (2001).

Similar results were reported by Kumar et al., (2016), Uikey et al., (2015), in pea, El- shimi et al., (2016) in sweet pepper, Kondappa et al., (2009) in chilli and Jhadav et al., (2014) in radish Vithwel and Kanaujia (2014) in carrot.

\section{Yield and yielding attributes}

In pea, longest $(10.29 \mathrm{~cm})$ and widest $(1.26$ $\mathrm{cm})$ pods were recorded in an integrated module in which $90 \%$ of RDF was sourced inorganically (Urea, SSP and MOP) and rest $10 \%$ organically through SMC on N eq. basis + recommended FYM + bio-fertilizers/PGPR $\left(\mathrm{T}_{6}\right)$ followed by on par pod size $(10.28 \times 1.22$ $\mathrm{cm}$ ) by another module i.e. $\mathrm{T}_{2}$ in which $10 \%$ of RDF was substituted organically through EC. In capsicum and radish also, the largest fruits $(6.06 \times 4.96 \mathrm{~cm})$ and roots $(18.80 \times 2.86$ $\mathrm{cm}$ ), respectively were observed through the same module $\left(\mathrm{T}_{6}\right)$ which determine largest pods in pea. 
Table.1 Effect of different INM treatments on growth parameters in pea-capsicum and radish cropping sequence

\begin{tabular}{|c|c|c|c|c|c|c|c|}
\hline \multirow[t]{3}{*}{ T.C } & \multirow[t]{3}{*}{ Treatments } & \multicolumn{6}{|c|}{ Growth Parameters } \\
\hline & & \multicolumn{2}{|c|}{ Pea } & \multicolumn{2}{|c|}{ Capsicum } & \multicolumn{2}{|c|}{ Radish } \\
\hline & & $\begin{array}{l}\text { Plant } \\
\text { height } \\
(\mathrm{cm})\end{array}$ & $\begin{array}{c}\text { No. of } \\
\text { branches }\end{array}$ & $\begin{array}{c}\text { Plant } \\
\text { height } \\
(\mathrm{cm})\end{array}$ & $\begin{array}{c}\text { No. of } \\
\text { branches }\end{array}$ & $\begin{array}{c}\text { Leaf } \\
\text { length } \\
(\mathrm{cm})\end{array}$ & $\begin{array}{c}\text { Leaf } \\
\text { breadth } \\
\text { (cm) }\end{array}$ \\
\hline 1 & $\mathrm{RPF}=(\mathrm{RDF}(\mathrm{NPK})+\mathrm{FYM})$ & 105.26 & 4.51 & 64.45 & 4.55 & 17.86 & 9.86 \\
\hline 2 & $90 \% \mathrm{RDF}+10 \% \mathrm{EC}+\mathrm{FYM}+$ bio-fertiliser/PGPR & 103.27 & 4.47 & 63.63 & 4.07 & 19.71 & 9.47 \\
\hline 3 & $80 \%$ RDF + 20\% EC + FYM + bio-fertiliser/PGPR & 101.95 & 4.05 & 56.98 & 3.94 & 18.78 & 8.37 \\
\hline 4 & $70 \%$ RDF + 30\% EC + FYM + bio-fertiliser/PGPR & 98.46 & 3.51 & 55.87 & 3.66 & 16.97 & 7.72 \\
\hline 5 & $60 \% \mathrm{RDF}+40 \% \mathrm{EC}+\mathrm{FYM}+$ bio-fertiliser/PGPR & 96.59 & 3.37 & 53.30 & 3.48 & 16.54 & 7.26 \\
\hline 6 & $90 \% \mathrm{RDF}+10 \% \mathrm{SMC}+\mathrm{FYM}+$ bio-fertiliser/PGPR & 104.41 & 4.82 & 64.25 & 4.47 & 21.01 & 9.88 \\
\hline 7 & $80 \%$ RDF + 20\% SMC + FYM + bio-fertiliser/PGPR & 102.19 & 4.25 & 58.08 & 4.38 & 19.72 & 8.04 \\
\hline 8 & $70 \% \mathrm{RDF}+30 \% \mathrm{SMC}+\mathrm{FYM}+$ bio-fertiliser/PGPR & 99.62 & 3.76 & 56.75 & 3.92 & 17.25 & 8.24 \\
\hline 9 & $60 \% \mathrm{RDF}+40 \% \mathrm{SMC}+\mathrm{FYM}+$ bio-fertiliser/PGPR & 97.03 & 3.49 & 54.31 & 3.48 & 16.50 & 7.78 \\
\hline 10 & $90 \%$ RDF + FYM + bio-fertiliser/PGPR & 103.41 & 4.38 & 63.38 & 3.88 & 18.55 & 9.22 \\
\hline 11 & $80 \%$ RDF + FYM + bio-fertiliser/PGPR & 100.87 & 3.92 & 56.74 & 3.79 & 16.94 & 7.72 \\
\hline 12 & $70 \%$ RDF + FYM + bio-fertiliser/PGPR & 98.12 & 3.45 & 55.63 & 3.68 & 16.55 & 7.75 \\
\hline 13 & $60 \%$ RDF + FYM + bio-fertiliser/PGPR & 94.86 & 3.19 & 52.66 & 3.33 & 16.68 & 7.00 \\
\hline & $\mathrm{CD}_{0.05}$ & 4.07 & 0.38 & 1.80 & 0.18 & 1.55 & 1.11 \\
\hline
\end{tabular}


Table.2 Effect of different INM treatments on yield and yield attributing parameters in pea-capsicum and radish cropping sequence

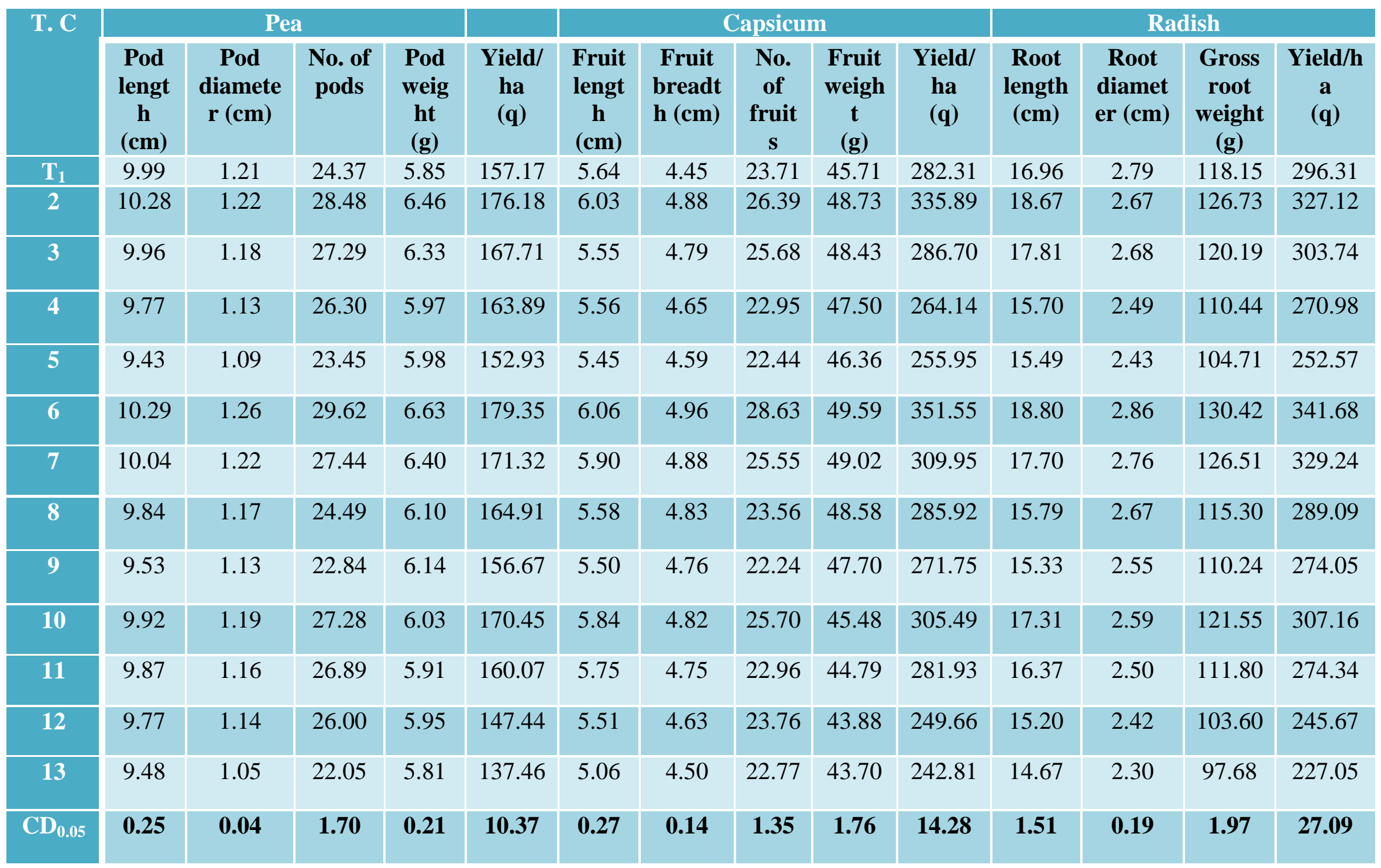


Similarly, number of pods/fruits and their unit weight, respectively was also highest in pea $(29.62,6.63 \mathrm{~g})$ and capsicum $(28.63,49.59 \mathrm{~g})$ through the same module i.e. $\mathrm{T}_{6}$ which recorded their largest size. In radish too, the highest unit weight was determined through $90 \% \mathrm{RDF}+10 \% \mathrm{EC}+\mathrm{FYM}+$ biofertiliser/PGPR i.e. $\mathrm{T}_{6}$. Relying on the better performance of direct attributes of yield i.e. size, number and weight, the module $\mathrm{T}_{6}$ with highest yield in pea $(179.35 \mathrm{q} / \mathrm{ha})$, capsicum $(351.55 \mathrm{q} / \mathrm{ha})$ and radish $(341.68 \mathrm{q} / \mathrm{ha})$ significantly excelled the recommended package of fertilization $\left(\mathrm{T}_{1}\right)$ which yielded @ 157.17, 282.31, and $296.31 \mathrm{q} / \mathrm{ha}$ in the above three crops, respectively. The overall, percent increase in yield through $T_{6}$ was to the tune of $14.11,24.53$ and $15.31 \%$ in these crops, respectively over the standard practice. In general, the yield in all the three crops improved significantly over the recommended practice (100\% NPK) when 10-20\% of recommended dose of NPK was substituted with either of the organic manures (EC or $\mathrm{SMC}$ ) on $\mathrm{N}$ eq. basis along with bio fertilizer's application to seeds and soil of respective plots. Thus, the finding suggests that reduction of $10-20 \%$ inorganics (NPK) is possible through their substitution with organic manures (EC, SMC) and bioinoculation of planting material with biofertilizers/PGPR. The results of present investigation in terms of yielding attributes and yield are in concordance with the findings reported by earlier researcher. Mukherjee in 2016 obtained maximum pea grain yield of $25.08 \mathrm{q} / \mathrm{ha}$ from a treatment module in which $75 \%$ of nutritional requirement was sourced through inorganic fertilisers and rest through vermicompost + Rhizobium + PSB vis-a-vis sole RDF which recorded 22.89 q/ha. Similarly, Sharma et al., (2014) obtained highest yield through vermicompost @ 20 $\mathrm{t} / \mathrm{ha}+75 \% \mathrm{NPK}+$ PGPR, which resulted in net saving of $25 \%$ NPK fertilizers along with average increase of $9.46,2.36$ and 1.14 per cent in yield over the recommended package of farmyard manure @ 20t/ha + $100 \%$ NPK in cauliflower, French bean and okra, respectively.Rani et al., (2015) also recorded higher green chilli yield on account of higher fruit number and weight when $150 \%$ of recommended dose of nitrogenous fertilizer was sourced half through inorganic and another half from organic sources viz. FYM $(25 \%)$ and Neem Cake (25\%) as basal and vermicompost as top dressing $(50 \%)$. The reasons for increased fruit yield in chilli were attributed to the increased solubilization effect and availability of nutrient by the addition of organics and increased physiological activity leading to the build-up of sufficient food reserves for the developing sinks and better portioning towards the developing fruits (Table 2).

Patil et al., (2016) exhibited the application of $50 \%$ RDF $+25 \% \mathrm{~N}$ through FYM $+25 \% \mathrm{~N}$ through vermicompost recording significantly higher root yield of carrot (24.10 t/ha) vis-avis $50 \% \mathrm{RDF}+50 \% \mathrm{~N}$ through FYM $(23.63$ $\mathrm{q} / \mathrm{ha}), 50 \% \mathrm{RDF}+50 \% \mathrm{~N} \mathrm{VC} \mathrm{(23.60} \mathrm{q/ha)}$ and $100 \% \operatorname{RDF}(23.38 \mathrm{q} / \mathrm{ha})$.

Therefore, it can be concluded that integrated module $\mathrm{T}_{6}(90 \% \mathrm{RDF}+10 \% \mathrm{SMC}+\mathrm{FYM}+$ Bio-fertilizer) resulted in saving of $10 \%$ of fertilizers (NPK), better growth and improving yield in mid hill condition of Himachal Pradesh. Hence, the integrated combination $\mathrm{T}_{6}(90 \% \mathrm{RDF}+10 \% \mathrm{SMC}+$ Bio-fertilizer/ PGPR) along with full recommended FYM as basal application can be suggested as cost effective combination for getting higher yield with grater quality on sustainable basis.

\section{References}

Alam, M. A. U. Hossain, M. A. Khatun, M. U. S. Islam, M. K. Anwar, M. M. and Haque, M. E. 2016. Effect of integrated nutrient management on yield and quality of sweet 
pepper. Journal of Biosciences and Agriculture Research 10:892-8.

Anonymous, 2011. Vision 2030 https://www.iivr.org.in (accessed July 10, 2017 at 3:30 pm). Indian Institute of Vegetable Research, Varanasi

Anonymous, 2015. Horticultural Statistics at a Glance 2015. Oxford University press. 437p.

Asghar, H. N. Ishaq, M. Zahir, Z. A. Khalid, M. and Arshad, M. 2006. Response of radish to integrated use of nitrogen fertilizer and recycled organic waste. Pakistan Journal of Botany 38:691-700.

Bhathal, S. and Kumar, R. 2016. Response of Integrated nutrient management on growth, yield and yield attributing characters of cluster bean (Cyamopsis tetragonoloba (L.) TAUB. Under irrigated conditions of Amritsar. International Journal in Management and Social Science 4:41-7

EL-Shimi, N. M. M. El- Sayeda, H. M. ElBadawy, and Tolba, H. I. 2015. Response of sweet pepper plants to some organic and biofertilizers and its effect on fruit yield and quality. Middle East Journal of Agriculture Research 4:435-445.

Gangwar, B. and Prasad, K. 2005. Cropping system management for mitigation of second generation problems in agriculture. Indian Journal of Agriculture Science 75: 65-68.

Jadhav, P. B. Patel, D. J. Kireeti, A. Patil, N. B. Dekhane, S. S. Harad, N. B. and Jadhav, K. P. 2014. Effect of different levels of vermicompost on growth and yield of radish cv. local variety. International Journal of Information Research and Review 2:29-31.

Kondapa, D. Radder, B. M. Patil, P. L. Hebsur, N. S. and Alagundagi, S. C. 2009. Effect of integrated nutrient management on growth, yield and economics of chilli (cv. Byadgi Dabba) in a vertisol. Karnataka Journal of Agricultural Sciences 22:438-40.

Kumar, A. Bharati, A. K. Singh, H. Pandey, H. C. and Rai, S. K. 2016. Effect of different sources of nutrients on growth, yield attributes and seed yield of field pea (Pisum sativum) in Bundelkhand region. Current Advances in Agricultural Sciences 8:109-1

Mukherjee, D. 2016. Integrated nutrient management practices on growth and yield of field pea (Pisum sativum L.) under mid hill condition. International Journal of Agricultural Sciences 12:309-3.

Panse, V. G. and Sukhatme, P. V. 2000. Statistical Methods for Agricultural Workers. Indian Council of Agricultural Research, New Delhi, India. 378p.

Patil, A. G. Mangesh, and Rajkumar, M. 2016. Integrated nutrient management in carrot (Daucus carrota) under north eastern transitional track of Karnataka. The Bioscan 11:271-3.

Rani, P. L. Balaswamy, K. Rao, A. R. and Masthan, S. C. 2015. Evaluation of integrated nutrient management practices on growth, yield and economics of green chilli cv. Pusa Jwala (Capsicum annuum L.). International Journal of Bio-resource and Stress Management. 6:76-80.

Sanyal, S. K. 2001. Colloidal chemical properties of humic substances: A Relook. Journal of Indian Society Soil Science 49:567-619.

Sheoran, O. P. Tonk, D. S., Kaushik LS, Hasija RC and Pannu RS. 1998. Statistical software package for agricultural research workers. In: Recent Advanes in Information Theory, Statistics and Computer Application (Hooda DS and Hasija RC eds). Department of mathematics statistics, CCS HAU, Hisar. pp. 139-3.

Uikey, V. Verma, H. and Nawange, D. 2015. Influence of organic, chemical and biofertilizer on growth and yield of pea. Agriculture Science Digest 35:237-40.

Vithwel, and Kanaujia, S. P. 2013. Integrated nutrient management on productivity of carrot and fertility of soil. SAARC Journal of Agriculture 11:173-81.

\section{How to cite this article:}

Monika Sharma, A.K. Sharma and Shilpa. 2018. Integrated Nutrient Management of PeaCapsicum-Radish Cropping Sequence in Sub-Temperate Climate of North-Western Himalayas. Int.J.Curr.Microbiol.App.Sci. 7(03): 538-545. doi: https://doi.org/10.20546/ijcmas.2018.703.064 